COMMENTARY ON COVID-19 AND THE FoOd SySTEM

\title{
Providing menu and shopping toolkits to improve food access and security during a pandemic
}

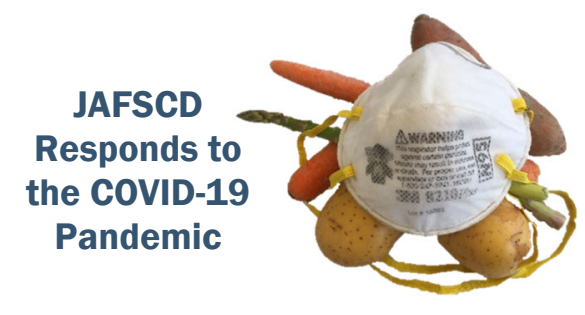

\author{
Kelly Kunkel, a * Abby Gold, ${ }^{\mathrm{b}}$ and Betsy Johnson c \\ University of Minnesota Extension
}

Submitted September 29, 2020 / Published online December 9, 2020

Citation: Kunkel, K., Gold, A., \& Johnson, B. (2020). Providing menu and shopping toolkits to improve food access and security during a pandemic. Journal of Agriculture, Food Systems, and Community Development, 10(1), 257-260. https://doi.org/10.5304/jafscd.2020.101.029

Copyright (C) 2020 by the Authors. Published by the Lyson Center for Civic Agriculture and Food Systems. Open access under CC-BY license.

\begin{abstract}
In response to COVID-19 stay-safe-at-home orders, the University of Minnesota Extension created and disseminated menu and shopping list toolkits for use by consumers and emergency food supply organizations. The menus were developed to use items commonly available from food pantries and small rural grocery stores. The menu and shopping toolkits have been useful to provide to consumers who are sheltering in place during the pandemic and may be useful to consumers and emergency food providers during other emergencies such as natural and human-made disasters that may limit access to food.
\end{abstract}

\section{Keywords}

COVID-19, Pandemic, Food Access, Food Insecurity, Menu, Toolkit, Grocery Shopping, Cooking, Emergency Food, Food Pantries

\footnotetext{
a * Corresponding author: Kelly Kunkel, MS, Extension Educator in Health and Nutrition, University of Minnesota Extension; 1961 Premier Drive, Suite 110; Mankato, Minnesota 56001 USA; +1-507-381-3861; kunke003@umn.edu

b Abby Gold, PhD, MPH, RD, Program Leader, Health and Nutrition, University of Minnesota Extension; agold@, umn.edu

${ }^{c}$ Betsy Johnson, MPH, Extension Educator in Health and Nutrition, University of Minnesota Extension.
}

\section{Funding Disclosure}

This project and the toolkits produced were funded as part of Minnesota's Supplemental Nutrition Assistance Program-Education grant from the Food and Nutrition Service of the U.S. Department of Agriculture. 


\section{Introduction}

With every day of the pandemic, vulnerable populations were put at greater risk for food insecurity due to loss of employment and supply chain disruptions resulting in rising food costs or lack of food availability. The federal government's response included providing waivers for school meal programs, changing and expanding eligibility criteria for Supplemental Nutrition Assistance Program (SNAP) benefits, and establishing the Farmers to Families Food Box. Individual states also authorized a variety of programs and funding. The governor of Minnesota allocated special dollars to food recovery programs and created a food security task force that reported directly to the governor's office.

Vulnerable populations, such as children and the elderly, are most affected by food insecurity. Chang and Hickman (2017) found that low-income older adults with functional limitations who lived alone faced three times higher odds of having a perceived poor-quality diet. Data from the Early Childhood Longitudinal Study - Kindergarten Cohort indicated that children experiencing any signs of food insecurity will learn less (Winicki \& Jemison, 2008). The short-term effects of food insecurity are obvious: reduced dietary quality and food variety, disrupted eating patterns, and reduced food intake (Wright et al., 2018). However, the long-term effects are less obvious, and include obesity, diabetes, hypertension, and slower growth and development in children.

Food insecurity, while endemic across the United States, was exacerbated by pandemic-related societal changes. The U.S. Census Household Pulse Survey reveals that in August 2020, 20\% of American households with children at home reported an inability to afford enough food, an increase from 17\% in June 2020 (Callen, 2020). One COVID-related study from a community health center in Texas reported food insecurity well above the usual 20\%-25\% rate expected among high-risk families with children, and almost four times that of U.S. households (Abrams, Avalos, Gray, \& Hawthorne, 2020). In response to the mid-March shutdown to slow the spread of COVID-19 and relieve the burden of food insecurity in already vulnerable populations, University of Minnesota Extension created a series of food access resources for consumers, rural grocery stores, and emergency food providers.

\section{Identified Need}

On March 15, 2020, Minnesota's governor ordered a temporary shutdown of the state's K-12 schools, quickly followed by an order for all nonessential businesses in the spring and fall of 2020. This abrupt shutdown forced an immediate change in daily habits, such as grocery shopping and meal preparation. In addition, fear and natural instinct resulted in a reaction of hoarding for those with the means to stock up on food and supplies. Another result was a mass loss of jobs in companies and organizations deemed nonessential. The combination of empty store shelves and more people without a paycheck created an immense strain on emergency food sources such as food pantries (also called food shelves) and soup kitchens.

Rural communities, already stretched for resources and supplies, were at risk of losing their local grocery stores as residents traveled to large communities to stock up at big-box stores. Rural food pantries experienced the loss of volunteers - typically older community members who were at increased risk of contracting the virus. Within the first week of the stay-safe-at-home order, it was clear that our community infrastructure partners needed help.

\section{Response}

Our first response, released on March 19, was a 14-day grocery list for rural grocery stores (Draeger, Gold, \& Olive, 2020). Developed and deployed by University of Minnesota Extension's Regional Sustainable Development Partnerships (RSDP), the list included a consumer menu and list of shelfstable foods to help a grocery store to prepare 20 kits. In addition, the RSDP released a tip sheet for 
rural grocery stores to safely distribute kits curbside.

To expand the useability of a 14-day grocery list, University of Minnesota's Extension for Family Development, Health \& Nutrition program created a menu and recipe toolkit that could be used by consumers and food pantries (Gold, 2020). This menu was designed for nutritional content with an emphasis on nutrients of special interest to older adults - those most at risk for the double threat of COVID-19 and poor nutrition. The meals and recipes were designed to use foods readily available at stores and food pantries. The kit included a shopping list to help guide consumers and food shelf volunteers to choose only the foods needed. Recipes were created or selected to accommodate inexperienced cooks and incomplete kitchens (for essential workers or others who lived in hotels or facilities without kitchens). Videos were developed that demonstrated how to prepare the recipes. The 2-week menu toolkit was distributed to rural and metropolitan food pantries and community partners who work with Extension's SNAP-Ed program.

Community partners quickly responded with requests for additional resources. Several of the resources were translated into Spanish and one resource into Somali. In response to the increased need for resources, Extension Health \& Nutrition educators created several additional resources:

1. A 14-day menu toolkit for using The Emergency Food Assistance Program (TEFAP) foods (University of Minnesota Extension, 2020d). This enhanced the efficiency of food pantries to provide food kits for families.

2. Feeding your Family with a Food Support Box (University of Minnesota Extension, 2020a) with ideas for using foods commonly found in food shelf boxes.

3. A COVID-19 hotel menu and shopping list (One Week Hotel Menu and Shopping List, [University of Minnesota Extension, 2020c] designed for health care and other essential workers who were quarantined or for individuals and families who would otherwise stay in shelters. Recipes were designed for use in a room equipped with a refrigerator, microwave, and coffee pot for preparing hot water.

4. The Cooking Without a Kitchen Guide (Erdahl \& Johnson, 2020) provides food lists and recipe suggestions for three scenarios: (1) No cooking equipment available, (2) hot water available, and (3) refrigerator and microwave available.

5. Help Keep your Grocery Store Safe (University of Minnesota Extension, 2020b) was designed specifically for Somali grocery stores (the resource is in Somali).

\section{Findings}

Between mid-March and the end of August, use of the guides and toolkits grew with the extension of stay-safe-at-home orders. As people return to work and businesses settle into a new normal, the guides and toolkits have become embedded in the routines of food pantries and community partners of our SNAP-Ed program. Since the menu kits were released in April and through mid-September, they have generated a great deal of interest. Social media reach for the menu toolkits (excluding the grocery store kit) total 31,851 for Facebook and 3,014 for Twitter (as of September 29, 2020).

\section{Conclusion and Application}

The food access resources created by Minnesota Extension in response to the COVID-19 stay-safe-athome governor's order proved useful for food access organizations and consumers to plan and prepare for healthier eating during extended periods between shopping trips. These guides and toolkits are applicable to any emergency where individuals and families must shelter at home. In Minnesota, blizzards and deep-freeze situations may prevent travel; throughout the U.S., storms and electric outages 
frequently prevent travel and access to food. The menu kits can be used to prepare and stock up prior to storm season, and the Cooking Without a Kitchen Guide can be used for meal preparation when there are no cooking facilities. All the resources are easily adapted to suit individual tastes and food availability.

\section{References}

Abrams, S. A., Avalos, A., Gray, M., \& Hawthorne, K. M. (2020). High level of food insecurity among families with children seeking routine care at federally qualified health centers during the coronavirus disease 2019 pandemic. Journal of Pediatrics: X, 4, 100044. https://doi.org/10.1016/j.ympdx.2020.100044

Callen, J. (2020, May). Weekly Census Bureau survey provides timely info on households during COVID-19 pandemic. Retrieved on September 17, 2020, from https://www.census.gov/library/stories/2020/05/new-household-pulsesurvey-shows-concern-over-food-security-loss-of-income.html

Chang, Y., \& Hickman, H. (2017). Food insecurity and perceived diet quality among low-income older Americans with functional limitations. Journal of Nutrition Education and Behavior, 50(5), 476-484. https://doi.org/10.1016/j.jneb.2017.09.006

Draeger, K., Gold, A., \& Olive, R. (2020). COVID-19/Emergency 14-day meal kit for rural grocery stores. UMN Extension Regional Sustainable Development Partnerships. Retrieved from http://hdl.handle.net/11299/212116

Erdahl, L., \& Johnson, B. (2020). Cooking without a kitchen. University of Minnesota Extension. Retrieved from https://extension.umn.edu/disaster-preparation-and-recovery/cooking-without-kitchen

Gold, A. (2020). Preparing a 2-week emergency food supply. University of Minnesota Extension. Retrieved from https://extension.umn.edu/how-prepare/preparing-2-week-emergency-food-supply

University of Minnesota Extension. (2020a). Feeding your family with a food support box. Retrieved from https://extension.umn.edu/building-better-food-shelves/feeding-your-family-food-support-box

University of Minnesota Extension. (2020b). Help keep your grocery store safe. Retrieved from https://extension.umn.edu/covid-19/help-keep-your-grocery-store-safe-somali-english

University of Minnesota Extension. (2020c). One week hotel menu and shopping list Retrieved from https://extension.umn.edu/disaster-preparation-and-recovery/cooking-without-kitchen

University of Minnesota Extension. (2020d). Two week menu guide. Retrieved from http://hdl.handle.net/11299/212401

Winicki, J., \& Jemison, K. (2008). Food insecurity and hunger in the kindergarten classroom: Its effect on learning and growth. Contemporary Economic Policy, 21(2), 145-157. https://doi.org/10.1093/cep/byg001

Wright, B. N., Bailey, R. L., Craig, B. A., Mattes, R. D., McCormack, L., Stluka, S., Eicher-Miller, H. A. (2018). Daily dietary intake patterns improve after visiting a food pantry among food-insecure rural midwestern adults. Nutrients, 10(5), 583. https://doi.org/10.3390/nu10050583 